\title{
INVESTIGATION OF WHEAT SOURDOUGH PREPARATION WITH USING OF STARTER LV1 FOR INCREASING OF SWEET DOUGH QUALITY
}

\author{
V. Yurchak, T. Noshchenko \\ National University of Food Technologies
}

S. Palyvoda, T. Golikova

LLC "Lesaffre Ukraine"

\begin{tabular}{l} 
Key words: \\
Wheat sourdough \\
Lactic acid bacteria \\
Starters \\
Quality indexes \\
Technological parameters \\
\hline
\end{tabular}

Article history:

Received 16.11.2018

Received in revised form

03.12.2018

Accepted 21.12.2018

Corresponding author:

V. Yurchak

E-mail:

npnuht@ukr.net

\begin{abstract}
The paper presents analyses of wheat sourdough using for producing of different bread types. It was shown that wheat sourdough may be used for increasing of taste and flavor of bread, preventing hardening of bread and for antimould effect as well as for intensification of technological process. Effect of sourdough on the bread quality is caused by microbiota content and parameters of technological process. Using sourdough is linked to the difficult process of its inoculation. Dry sourdough - dry lactobacterin, starters are perspective for using in baking technology.

Lesaffre is a company of baking ingredients - developed dry sourdough of starters LV1, LV2, LV4 that contain homo- and heterofermentative lactic acid bacteria and yeast Saccharomyces Chevalieri. Company recommends using these starters for sweet dough and yeast-free bread. Features of using depends on the goal.

The impact of parameters of sourdough preparation by starter LV1 - moisture, fermentation temperature - to the acidity, rising power and fermentation time has been investigated. It has been shown the acidity and rising power of stiff sourdough are higher compared to liquid sourdough. The abidance of higher temperature of sourdough $-28^{\circ} \mathrm{C}$ support to faster achievement of the required sourdoughs acidity and allows to reduce the process of their fermentation.

It has been proved that in the case of using liquid wheat sourdough based on the starter LV1 as an acidifier it is rational to use the sourdough in the amount of $50 \%$ to the mass of flour in the dough. In the case of using the sourdough based on the starter LV1 as a rising agent it is expedient to use a stiff sourdough in the amount containing $20 \%$ of flour and add $0.2 \%$ of compressed yeast to the final dough.

Effect of recipe components on the quality of sourdough has been investigated. Comparative estimation of products' quality made by different ways has been given. Sourdough increases volume of bread, content of aromatic components and crumb structure as well as shelf life of bread.
\end{abstract}

DOI: $10.24263 / 2225-2924-2018-24-6-27$ 


\title{
ДОСЛІДЖЕННЯ ПРОЦЕСУ ПРИГОТУВАННЯ \\ ПШЕНИЧНИХ ЗАКВАСОК 3 ВИКОРИСТАННЯМ СТАРТОВОЇ КУЛЬТУРИ LV1 ДЛЯ ПОЛІПШЕННЯ ЯКОСТІ ХЛІБА І ЗДОБНИХ ВИРОБІВ
}

\author{
В.Г. Юрчак, Т.І. Нощенко \\ Національний університет харчових технологій \\ С.Д. Паливода, Т.П. Голікова \\ ТОВ «Лесаффр Украӥна»
}

У статті проаналізовано використання пшеничних заквасок для виготовлення різних сортів хліба. Показано, що пшеничні закваски можуть використовуватись для поліпшення смакових властивостей хліба, запобігання його черствінню та мікробіологічнму псуванню, інтенсифікаиї̈ технологічних процесів. Використання заквасок пов'язане зі складним процесом їх розведення. Перспективним є використання сухих препаратів заквасок сухого лактобактерину, сухих заквасок, що містять так звані стартові культури мікроорганізмів.

Компанія Lesaffre розробила ряд стартових культур LV1, LV2, LV4, щзо містять гомоферментативні та гетероферментативні молочнокислі бактерії $і$ дріжджі підвиду Saccharomyсеs Chevalieri. Компанія рекомендує використання цих заквасок для виготовлення хліба та здобних виробів і позииіонує ичі вироби як бездріжджові. Особливості приготування циих заквасок залежать від мети застосування.

У статті досліджено вплив параметрів приготування закваски на основі стартової культури LVI - вологості, температури - на кислотність, підйомну силу й тривалість бродіння заквасок. Показано, щео кислотність $i$ підйомна сила густих заквасок є вищими порівняно з рідкими заквасками. Дотримання вищої температури заквасок $-28^{\circ} \mathrm{C}$ сприяє швидиому досягненню необхідної кислотності заквасок та дає змогу скоротити процес їх бродіння.

Доведено, що в разі використання рідкої пшеничної закваски на стартовій культурі LVI як підкислювача рачіонально вносити закваску при приготуванні тіста в кількості 50\% до маси борошна в тісті. При використанні закваски на стартовій культурі LV1 як розпушувача для приготування хліба дочільно використовувати густу закваску в кількості, що містить $20 \%$ борошна,та вносити в тісто 0,2\% до маси борошна пресованих дріжджів.

Визначено вплив рецептурних компонентів на показники якості заквасок. Дано порівняльну оцінку якості виробів, виготовлених різними способами, та встановлено, що у разі приготування виробів із застосуванням заквасок поліпшується об'єм виробів, зростає вміст ароматутворюючих речовин, покращується стан м'якушки та збереження свіжості хліба.

Ключові слова: пшеничні закваски, молочнокислі бактерії, стартові культури, показники якості, технологічні параметри. 
Постановка проблеми. Нині у хлібопекарській галузі для виробництва пшеничних хлібобулочних виробів часто застосовують прискорені безопарні способи приготування тіста. Це призводить до зниження смакових властивостей виробів, швидшого їх черствіння і навіть до мікробіологічного псування.

Одним із способів поліпшення якості пшеничних хлібобулочних виробів $\epsilon$ використання пшеничних заквасок - мезофільних молочнокислих заквасок (ММКЗ), концентрованих молочнокислих заквасок (КМКЗ), а також різних заквасок зі спрямованим культивуванням мікроорганізмів: пропіоновокислих, ацидофільних, комплексних, вітамінних, ергостеринових пшеничних заквасок тощо [1; 2]. Найбільшого поширення в промисловості набули ММКЗ та КМКЗ. Ці закваски використовують при опарних способах приготування тіста для запобігання захворюванням хліба картопляною хворобою та у разі приготування тіста прискореними способами для підвищення кислотності хліба і поліпшення смакової якості.

Цикл розведення цих заквасок здійснюють із використанням чистих культур бактерій або з використанням сухого лактобактерину. Використання чистих культур для розведення заквасок $\epsilon$ трудомісткою і складною процедурою [4]. Сухий лактобактерин для пшеничних заквасок був розроблений Санкт-Петербурзьким відділенням ДержНДІХП Росії спільно $з$ підприємством $з$ виробництва бактеріальних препаратів $[1 ; 3]$. Застосування сухого лактобактерину в хлібопекарській промисловості має ряд переваг: значно скорочується цикл розведення заквасок, немає необхідності у складному мікробіологічному обладнанні, у приготуванні стерильних поживних середовищ, сухі препарати чистих культур можуть довго зберігатись. Проте існує досить обмежений спектр таких препаратів.

Водночас на ринку України з'явились препарати стартових культур для заквасок з країн $Є С$, призначені для виробництва пшеничного хліба, що містять нові штами молочнокислих бактерій (МКБ) та дріжджів і відкривають можливість поліпшення якості пшеничних хлібобулочних виробів в нашій країні [5].

Аналіз останніх досліджень і публікацій. Представництво французької компанії Lesaffre TOB «Лесаффр Україна» пропонує стартову культуру для приготування заквасок LV1, яка містять молочнокислі гомоферментативні бактерії Lactobacillus casei та гетероферментативні бактерії Lactobacillus brevis і дріжджі виду Saccharomyces cerevisiae підвиду Saccharomyces Chevalieri [5]. Отже, ці закваски, на відміну від ММКЗ та КМКЗ, містять дріжджі, тому $\epsilon$ дріжджовими заквасками, які можуть не тільки підкислювати тісто, але й розпушувати його.

Молочнокисле бродіння відіграє важливу роль у формуванні смаку й аромату хліба. Гомоферментативні МКБ під час зброджування гексоз утворюють молочну кислоту й ароматичні речовини; гетероферментативні, крім молочної, утворюють оцтову кислоту, спирт, невелику кількість діоксиду вуглецю та інші продукти [6;7]. Молочна кислота надає хлібу виражений аромат закваски, оцтова кислота є посилювачем кислого смаку та робить його дещо різким. На співвідношення молочної оцтової кислот у напівфабрикатах впливає ряд факторів: сорт борошна, вологість напівфабрикату, його температура. Наприклад, за температури $30^{\circ} \mathrm{C}$ утворюється більше молочної кислоти, а за 
температури нижче $25^{\circ} \mathrm{C}$ - більше оцтової. Зі збільшенням вологості напівфабрикатів зростає активність гомоферментативних бактерій і посилюється накопичення молочної кислоти [8; 9]. Внаслідок бродіння закваски на основі стартової культури LV1 відбувається накопичення молочної та оцтової кислот у співвідношенні 11:1, завдяки чому вироби набувають ніжного молочнокислого аромату.

Особливе значення надається штаму дріжджів, які містяться у цих заквасках. Вони є мальтозоіндиферентними, тобто не містять мальтази і не зброджують мальтозу. Отже, вони можуть зброджувати власні цукри борошна, вміст яких невисокий, або внесений у тісто цукор [10]. Ці дріжджі беруть участь не тільки в розпушенні тіста, але й у формуванні смаку хліба та мають високу компліментарність з використовуваними бактеріями.

Компанія Lesaffre рекомендує використання заквасок на основі стартової культури LV1 для виробів класу «Преміум» - «Пен о левен», виробів здобних «Бріош», «Панеттон» тощо. Для здобних виробів рекомендується використовувати ці закваски 3 додаванням або без додавання пресованих дріжджів (залежно від рецептури), а для хліба - 3 внесенням невеликої кількості пресованих дріжджів. Тому компанія позиціонує ці вироби як бездріжджові [5].

В інструкціях щодо використання цих заквасок наводяться технологічні параметри для приготування різних сортів хлібобулочних виробів з їх застосуванням.

Водночас для ефективного управління технологічними процесами технологу важливо знати закономірності зміни показників якості напівфабрикатів за впливу різних технологічних факторів на перебіг процесів приготування, та показники якості готових виробів, виготовлених за різними технологіями iз застосуванням цих заквасок. Для встановлення параметрів поновлення заквасок, призначених для виготовлення різного асортименту виробів, необхідно встановити вплив кількості взятої на поновлення закваски на показники якості напівфабрикатів і тривалість бродіння закваски.

Мета дослідження: вивчення закономірностей зміни основних показників якості й готовності заквасок від технологічних факторів та обгрунтування раціональних параметрів їх приготування для різного асортименту виробів.

Викладення основних результатів дослідження. Вивчали вплив температури, вологості заквасок на кінетику їх кислотності, підйомної сили та газоутворення в тісті при приготуванні хліба та здобних виробів. Досліджували кінетику кислотонакопичення та зміну підйомної сили заквасок з вологістю $50 \%$ та $65 \%$ за температури $22^{\circ} \mathrm{C}$ та $28^{\circ} \mathrm{C}$ впродовж 24 год бродіння. Встановлено (рис. 1), що за температури бродіння $28^{\circ} \mathrm{C}$ густа закваска за 24 год досягає вищої кислотності, ніж рідка, і становить, відповідно, 10 град. і 8 град. Проте протягом перших 6 год бродіння кислотність заквасок майже не змінювалась і становила 2 град., протягом наступних 6-7 год зростала на 1 град., i лише після 14 год бродіння наростання кислотності відбувалось швидше приблизно на 0,5-0,6 град. щогодини, причому кислотність густої закваски була вищою і через 20 год бродіння кислотність становила 8 град. і 6 град. для густої і рідкої закваски відповідно, а через 24 год - 10 та 8 град. 


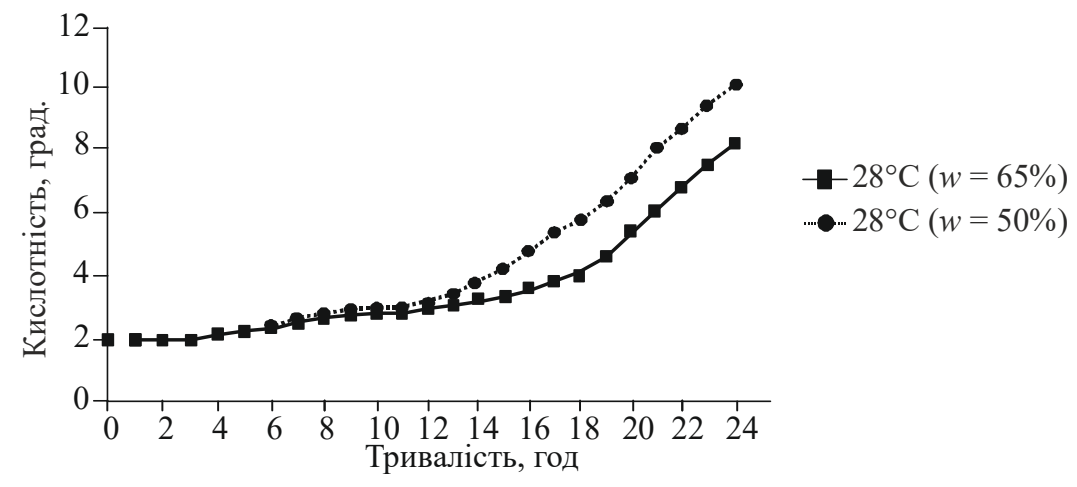

Рис. 1. Залежність зміни кислотності заквасок на стартових культурах LV1 з вологістю $50 \%$ та $65 \%$ за температури $28^{\circ} \mathrm{C}$

Залежність кислотонакопичення в процесі бродіння густої і рідкої закваски за температури $22^{\circ} \mathrm{C}$ показано на рис. 2. Як видно 3 наведених даних, протягом 9 год бродіння кислотність заквасок практично не змінювалась $\mathrm{i}$ становила 2-2,2 град., протягом наступних 9 год зростала на 1 град., а після 18 год культивування кислотність суттєво зростала як для густої, так і для рідкої закваски і становила в кінці бродіння через 24 год 5 град. і 4,5 град. для густої та рідкої закваски відповідно.

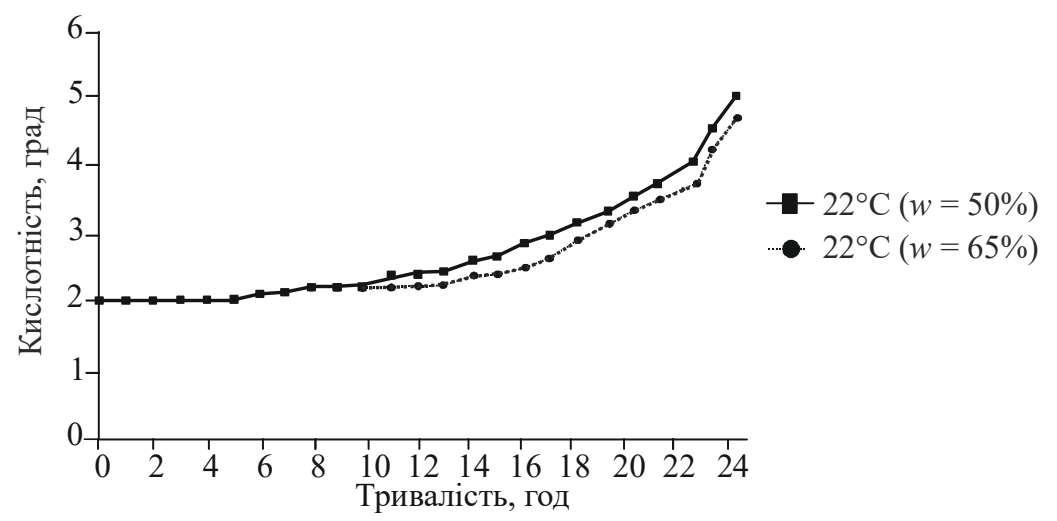

Рис. 2. Залежність зміни кислотності заквасок на стартових культурах LV1 з вологістю $50 \%$ та $65 \%$ за температури $22^{\circ} \mathrm{C}$

Тож можна зробити висновок, що температура закваски суттєво впливає на іiі кислотність в кінці бродіння. Після 24 год бродіння за температури $28^{\circ} \mathrm{C}$ кислотність заквасок $\epsilon$ вдвічі вищою і становить 8-10 град. порівняно 3 кислотністю заквасок, що бродили за температури $22^{\circ} \mathrm{C}$. В густих заквасках кислотонакопичення відбувається інтенсивніше.

Визначали газоутворення в тісті, замішаному на густих заквасках, виброджених за температури $22^{\circ} \mathrm{C}$ і $28^{\circ} \mathrm{C}$. Встановлено, що температура бродіння закваски незначно впливає на газоутворення в тісті. Але помітно, що газоутворювальна здатність закваски, яка бродила при температурі $28^{\circ} \mathrm{C}, \epsilon$ трохи вищою і становить для тіста на густій заквасці $180 \mathrm{~cm}^{3} / 100$ г тіста. 
Вивчення впливу вологості закваски на іï підйомну силу (за методом спливання кульки тіста) впродовж 24 год бродіння свідчить (табл. 1), що підйомна сила рідкої закваски $є$ нижчою, але поліпшується впродовж 24 год бродіння. Підйомна сила густої закваски $є$ приблизно в три рази вищою (час спливання кульки тіста скорочується в три рази), але після 16 год бродіння дещо знижується. Останнє можна пояснити зниженням вмісту зброджуваних цукрів у заквасці в кінці бродіння.

Таблиця 1. Вплив тривалості бродіння та вологості закваски на стартовій культурі LV1 на їі підйомну силу

\begin{tabular}{|c|c|c|}
\hline Тривалість & \multicolumn{2}{|c|}{ Підйомна сила закваски, хв } \\
\cline { 2 - 3 } бродіння, год & рідкої $(w=65 \%)$ & густої $(w=50 \%)$ \\
\hline 4 & 36 & 12 \\
\hline 8 & 34 & 11 \\
\hline 16 & 31 & 12 \\
\hline 24 & 30 & 20 \\
\hline
\end{tabular}

Аналіз впливу вологості закваски на підйомну силу свідчить, що густі закваски краще використовувати як розпушувачі, а рідкі — для підкислення напівфабрикатів за прискорених способів тістоприготування. Тому в подальших дослідженнях вивчали використання закваски на стартовій культурі LV1 при виготовленні хліба прискореним способом. Тісто готували прискореним безопарним способом 3 додаванням $1 \%$ пресованих дріжджів до маси борошна. Використовували рідку закваску на стартовій культурі LV1, кислотність якої в кінці бродіння становила 8 град., в кількості 25\%, 50\% та $75 \%$ до маси борошна в тісті, що відповідало $10 \%, 20 \%$ та $30 \%$ борошна в заквасці від усієї кількості. Тісто замішували на двошвидкісній машині протягом 5 хв на першій швидкості та 2 хв на другій, за температури $24-26^{\circ} \mathrm{C}$ тривалість бродіння становила 60 хв. Контролювали показники, що характеризують властивості тіста, кількість і якість клейковини та показники якості хліба: питомий об’єм, H/D, кислотність. Результати дослідження наведені в табл. 2.

Таблиия 2. Вплив дозування закваски на якість напівфабрикатів і хліба

\begin{tabular}{|c|c|c|c|c|}
\hline \multirow{2}{*}{ Показники } & \multicolumn{4}{|c|}{ Кількість внесеної закваски, \% до маси борошна } \\
\cline { 2 - 5 } & $\begin{array}{c}\text { Контроль } \\
\text { (без закваски) }\end{array}$ & 25 & 50 & 75 \\
\hline Кислотність тіста, град. & 1,9 & 2,1 & 2,8 & 3,6 \\
\hline $\begin{array}{c}\text { Газоутримувальна здатність тіста, } \\
\text { см }{ }^{3} / 100 \text { г за 1 год }\end{array}$ & 110 & 120 & 140 & 110 \\
\hline $\begin{array}{c}\text { Формостійкість за розпливанням } \\
\text { кульки за 3 год, мм }\end{array}$ & 9,4 & 10,3 & 10,5 & 11,3 \\
\hline Кількість сирої клейковини,\% & 13,1 & 13,0 & 12,9 & 13,0 \\
\hline Розтяжність клейковини, см & 13,8 & 13,8 & 12,5 & 12,2 \\
\hline ИДК, од. приладу & 87 & 78 & 70 & 66 \\
\hline Кислотність хліба, град. & 1,8 & 2,0 & 3,0 & 3,6 \\
\hline Питомий об’єм хліба, см $3 / 100$ г & 245 & 242 & 267 & 253 \\
\hline Н/D хліба & 0,56 & 0,55 & 0,53 & 0,53 \\
\hline
\end{tabular}


Досліди показали, що збільшення дозування закваски до 75\% знижує газоутримувальну здатність та формостійкість тіста, клейковина стає більш пружною. Найкраща якість хліба спостерігалась за дозування закваски 50\%. Смак та аромат готових виробів зі збільшенням дозування закваски стає більш вираженим. У разі внесення $75 \%$ закваски дещо зменшувався питомий об'єм хліба та відчувався кислий смак.

Було визначено вміст ароматутворюючих речовин у хлібі, виготовленому 3 використанням заквасок. Для дослідження випікали три зразки хліба: контрольний (без внесення закваски), хліб з внесенням рідкої закваски як підкислювача у кількості $50 \%$ та хліб, виготовлений на густій заквасці, яка $є$ розпушувачем (табл. 3).

Таблиця 3. Вплив заквасок на стартовій культурі LV1 на вміст ароматутворюючих речовин у хлібі

\begin{tabular}{|c|c|c|c|}
\hline Показник & Хліб без & \multicolumn{2}{|c|}{ Хліб на заквасці } \\
\cline { 3 - 4 } & заквасок & рідкій & густій \\
\hline $\begin{array}{c}\text { Вміст бісульфітзв'язуючих речовин, мл 0,1 } \\
\text { моль/дм }{ }^{3} \text { розчину йоду }\end{array}$ & 12,7 & 15,5 & 16,4 \\
\hline
\end{tabular}

Встановлено, що при внесенні рідкої закваски вміст бісульфітзв'язуючих речовин збільшується на 22\% порівняно 3 хлібом, виготовленим безопарним способом на пресованих дріжджах, а при використанні густої закваски як розпушувача вміст бісульфітзв'язуючих речовин зростає на $29,2 \%$.

Отже, оптимальне дозування рідкої закваски як підкислювача становить 50 \% або кількість закваски, що містить 20\% борошна.

Наведені вище результати дослідження показали, що кращу підйомну силу мають густі закваски. Тому нами були проведені дослідження з приготування хліба на густих заквасках як розпушувачах. При цьому компанія Lesaffre рекомендує вносити в тісто $0,2 \%$ до маси борошна в тісті пресованих дріжджів. Оскільки кислотність густих заквасок вища, ніж рідких, кількість закваски, що вносилась у тісто, була меншою і становила $10 \%$ та $20 \%$ в перерахунку на борошно, що вноситься із закваскою, або $15,75 \%$ та $31,5 \%$ закваски до маси борошна в тісті. Щоб перевірити доцільність використання пресованих дріжджів, готували зразки на заквасках без дріжджів та з використанням заквасок і 0,2\% пресованих дріжджів. Оскільки кислотність густої закваски, що бродила 24 год, за температури $28^{\circ} \mathrm{C} є$ зависокою для пшеничного хліба - 10 град., закваску готували у двох варіантах: за температури бродіння $28^{\circ} \mathrm{C}$ i тривалості бродіння 20 год та за температури бродіння $22^{\circ} \mathrm{C}$ і тривалості бродіння 24 год. При температурі бродіння закваски $28^{\circ} \mathrm{C}$ iї вносили у тісто в кількості $15,75 \%$ та $31,5 \%$ до маси борошна в тісті. При температурі бродіння $22^{\circ} \mathrm{C}$ кислотність закваски $є$ нижчою, тому іiі вносили лише в кількості 31,5\%. Результати дослідження наведені в табл. 4.

Аналіз якості готових виробів показав, що найбільший питомий об'єм має зразок, де дозування борошна в закваску температурою $28^{\circ} \mathrm{C}$ становить $20 \%$ та 3 внесенням дріжджів $0,2 \%$ до маси борошна в тісті. Отже, внесення невеликої кількості пресованих дріжджів у тісто $(0,2 \%)$ дає змогу скоротити тривалість бродіння тіста і вистоювання тістових заготовок та сприяе зростанню 
питомого об’єму хліба. Кислотність тіста і хліба у цьому випадку знижується незначно.

Табличя 4. Вплив параметрів приготування густої закваски та тіста на якість напівфабрикатів і хліба

\begin{tabular}{|c|c|c|c|c|c|c|}
\hline \multirow{2}{*}{ Показники } & \multicolumn{3}{|c|}{ Температура закваски, ${ }^{\circ} \mathrm{C}$, тривалість бродіння, год } \\
\cline { 2 - 7 } $22^{\circ} \mathrm{C}, 24$ год & \multicolumn{4}{c|}{$28^{\circ} \mathrm{C}, 20$ год } \\
\hline Кислотність закваски, град. & \multicolumn{2}{|c|}{2,5} & \multicolumn{3}{|c|}{6,6} \\
\hline $\begin{array}{c}\text { Кількість борошна в заквасці, } \% \\
\text { до маси борошна в тісті }\end{array}$ & \multicolumn{2}{|c|}{$20 \%$} & \multicolumn{2}{|c|}{$10 \%$} & \multicolumn{2}{c|}{$20 \%$} \\
\hline $\begin{array}{c}\text { Кількість дріжджів, } \\
\text { \% до маси борошна в тісті }\end{array}$ & - & $0,2 \%$ & - & $0,2 \%$ & - & $0,2 \%$ \\
\hline Тривалість бродіння тіста, хв & 120 & 90 & 120 & 90 & 120 & 90 \\
\hline Кислотність тіста, град. & 2,0 & 2,0 & 2,8 & 2,6 & 3,0 & 2,8 \\
\hline $\begin{array}{c}\text { Питомий об'єм тіста через 3 год } \\
\text { бродіння, см }{ }^{3} / 100 \text { г тіста }\end{array}$ & 130 & 170 & 100 & 130 & 140 & 180 \\
\hline $\begin{array}{c}\text { Тривалість вистоювання до } \\
\text { готовності, хв }\end{array}$ & 150 & 120 & 150 & 120 & 150 & 120 \\
\hline Кислотність хліба, град. & 2,2 & 2,0 & 3,2 & 2,6 & 4,0 & 3,8 \\
\hline Питомій об’єм хліба, см ${ }^{3} / 100 г$ & 230 & 306 & 179 & 247 & 246 & 307 \\
\hline Н/D подового хліба & 0,55 & 0,57 & 0,60 & 0,55 & 0,60 & 0,50 \\
\hline
\end{tabular}

Незначно відрізняється за питомим об'ємом зразок з дозуванням закваски $20 \%$ та кількістю дріжджів 0,2\%, де температура бродіння закваски була $22^{\circ} \mathrm{C}$. Проте у цьому варіанті, хоча тривалість бродіння закваски була більшою на 4 год, кислотність хліба суттєво нижча.

Як зазначено вище, використання стартових культур для розведення закваски в один цикл суттєво здорожує продукцію. Для можливості безперервного ведення пшеничних заквасок на стартовій культурі необхідно дослідити процес поновлення заквасок. В роботі процес поновлення заквасок здійснювали для густих заквасок за внесення стиглої закваски у кількості 10, 30 та 50\% до загальної кількості закваски. Стигла закваска бродила 24 год за температури $28^{\circ} \mathrm{C}$ і мала кислотність 9,8 град. і підйомну силу 108 хв. При цьому ставилось завдання встановити час бродіння заквасок у циклі поновлення до досягнення необхідної кислотності. Отримані дані наведені на рис. 3 та рис. 4.

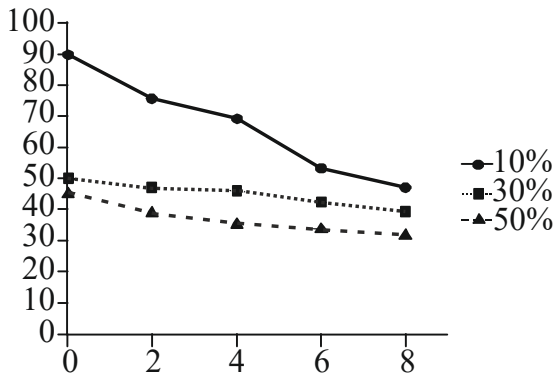

Рис. 3. Залежність зміни кислотності густої закваски у процесі поновлення 3 використанням $10 \%, 30 \%, 50 \%$ стиглої закваски

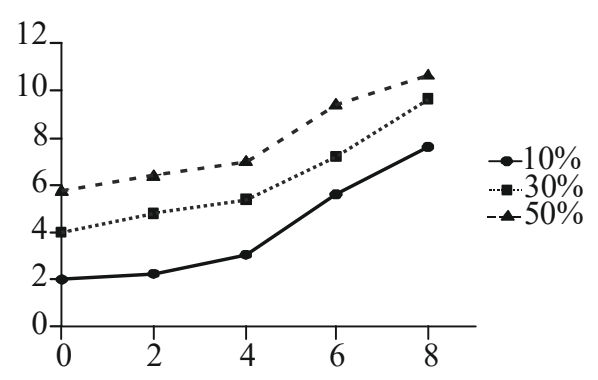

Рис. 4. Зміна підйомної сили густої закваски у процесі поновлення 3 використанням $10 \%, 30 \%, 50 \%$ стиглої закваски 
Встановлено (рис. 3), що початкова кислотність закваски після поновлення збільшується зі збільшенням кількості закваски на поновлення і становила 2 град. у разі внесення 10\% стиглої закваски, 4 град. - у разі внесення $30 \%$ стиглої закваски і 6 град. за внесення 50\% стиглої закваски. За 8 год бродіння кислотність поновлених заквасок досягала, відповідно, 8 град., 9,8 та 10,5 град. Як показано вище, кислотність закваски 10 град. забезпечує необхідну кислотність виробів. Отже, внесення стиглої закваски на поновлення в кількості $30-50 \%$ забезпечує досягнення необхідної кислотності поновленої закваски за 8 год бродіння. Підйомна сила заквасок за цей час поновлення становить, відповідно, 50 хв, 40 хв та 30 хв.

Компанією Lesaffre розроблені технологічні рекомендації з виготовлення різного асортименту виробів $з$ використанням заквасок на стартових культуpax, зокрема, здобних виробів. У Франції до традиційних здобних виробів відносять бріош, який може виготовлятись за різними рецептурами. Залежно від рецептури виробів тісто для їх виготовлення можуть готувати на заквасках 3 додаванням пресованих дріжджів або без них. Нами була проведена порівняльна оцінка якості готових виробів бріош, виготовлених за різними технологіями: за приготування тіста безопарним способом, опарним способом та на заквасках з використанням стартової культури LV1. Рецептури приготування кожного зразка наведені в табл. 5.

Тісто безопарне замішували 3 використанням 4\% пресованих дріжджів, опарне - 3 використанням 3\% дріжджів, тісто на заквасках готувалось без додавання пресованих дріжджів з внесенням у закваску $0,25 \%$ до маси борошна стартової культури LV1. В опару вносили 50\% борошна, дріжджі та всю воду, необхідну для приготування тіста; в закваску - 50\% борошна, стартову культуру, частину цукру та жиру - по 2,5 \% до маси борошна в тісті, частину солі. Решту сировини вносили у тісто. Тривалість бродіння тіста становила 60 хв. Остаточне вистоювання проводили до готовності тістових заготовок. Показники якості виробів наведені в табл. 6.

Таблиия 5. Рецептура приготування тіста безопарним, опарним способом і на заквасці

\begin{tabular}{|c|c|c|c|c|c|}
\hline \multirow{2}{*}{ Найменування сировини } & \multirow{2}{*}{$\begin{array}{c}\text { Бріош безопарним } \\
\text { способом }\end{array}$} & \multicolumn{2}{|c|}{ Бріош на опарі } & \multicolumn{2}{c|}{ Бріош на заквасці } \\
\cline { 3 - 6 } & 100,0 & 50,0 & 50,0 & 50,0 & 50,0 \\
\hline Борошно пшеничне в/с & 4,0 & 3,0 & - & - & - \\
\hline $\begin{array}{c}\text { Дріжджі хлібопекарські } \\
\text { пресовані }\end{array}$ & 18,0 & - & 18,0 & 2,5 & 15,5 \\
\hline Цукор білий кристалічний & 2,0 & - & 2,0 & 0,7 & 1,3 \\
\hline Сіль кухонна харчова & 20,0 & - & 20,0 & 2,5 & 17,5 \\
\hline Масло вершкове & 20,0 & - & 20,0 & - & 20,0 \\
\hline Яйця курячі & 30,0 & 30,0 & - & 25,0 & 5,0 \\
\hline Вода & - & - & - & 0,25 & - \\
\hline Стартова культура LV1 & \multicolumn{7}{|c}{} \\
\hline
\end{tabular}

Експериментальні дані свідчать, що бріош, виготовлений безопарним способом з використанням найбільшої кількості пресованих дріжджів, має найбільший питомий об'єм, але поступається іншим виробам за органолептичними показниками, містить менше ароматутворюючих речовин і має нижчу 
кислотність. Бріош, виготовлений на заквасках, має питомий об'єм і органолептичні показники такі, як і при опарному способі тістоприготування, але містить найбільше ароматутворюючих речовин, краще зберігає властивості м'якушки, зокрема має найнижчу крихкуватість м'якушки.

Таблиця 6. Показники якості виробів бріош, виготовлених безопарним, опарним способом тістоприготування і на заквасці

\begin{tabular}{|c|c|c|c|}
\hline \multirow[b]{2}{*}{$\begin{array}{c}\text { Показники якості } \\
\text { виробів }\end{array}$} & \multicolumn{3}{|c|}{ Спосіб тістоприготування } \\
\hline & $\begin{array}{c}\text { Бріош безопарним } \\
\text { способом }\end{array}$ & Бріош на опарі & Бріош на заквасці \\
\hline Структура пористості & \multicolumn{3}{|c|}{$\begin{array}{c}\text { Пори дрібні, тонкостінні, рівномірно розподілені } \\
\text { по всій поверхні }\end{array}$} \\
\hline Смак & $\begin{array}{c}\text { Недостатньо } \\
\text { виражений, } \\
\text { характерний для } \\
\text { хліба }\end{array}$ & \multicolumn{2}{|c|}{$\begin{array}{c}\text { Інтенсивно виражений, характерний } \\
\text { для хліба }\end{array}$} \\
\hline Аромат & $\begin{array}{c}\text { Недостатньо } \\
\text { виражений, } \\
\text { властивий для хліба }\end{array}$ & \multicolumn{2}{|c|}{$\begin{array}{c}\text { Інтенсивно виражений, властивий для } \\
\text { хліба }\end{array}$} \\
\hline Стан поверхні & \multicolumn{3}{|c|}{ Бездоганно гладенька, без тріщин і підривів, глянцева } \\
\hline Колір м'якушки & Дуже світла & \multicolumn{2}{|c|}{ Світла, 3 жовтим відтінком } \\
\hline Питомий об'єм, см³ $/ 100 \Gamma$ & 526 & 454 & 455 \\
\hline Кислотність, град. & 2,8 & 3,0 & 4,0 \\
\hline $\begin{array}{l}\text { Деформація м'якушки, од. } \\
\text { пенетромера, через } 24 \text { год }\end{array}$ & 130 & 98 & 116 \\
\hline Крихкуватість, \% & 6,8 & 15,5 & 6,1 \\
\hline $\begin{array}{l}\text { Вміст ароматичних речовин, } \\
\text { мл } 0,1 \text { н розчину йоду } \\
\text { в } 100 \text { г СР }\end{array}$ & 24,2 & 26,2 & 28,4 \\
\hline
\end{tabular}

Особливістю приготування заквасок для виготовлення бріошів $є$ внесення частини додаткової сировини в закваску. Для обгрунтування доцільності цієї операції та пояснення значення внесення окремих рецептурних компонентів у закваску проводили досліди, в яких готували закваску без внесення додаткової сировини, з внесенням цукру в кількості $2,5 \%$ до маси борошна в тісті, 3 внесенням жиру в кількості $2,5 \%$ та із сумісним використанням цукру та жиру. Бродіння зразків проводилось за температури $28^{\circ} \mathrm{C}$, вологість закваски становила $39 \%$. Визначали вплив рецептурних компонентів на кислотонакопичення і зміну підйомної сили впродовж 16 год з інтервалом 4 год. Аналізували якість хліба, випеченого з використанням цих заквасок (табл. 7).

Встановлено, що використання цукру незначно інтенсифікує підвищення кислотності закваски, але поліпшує її підйомну силу, що пояснюється збільшенням у заквасці кількості зброджуваних цукрів, оскільки дріжджі $S$. Chevalieri не зброджують мальтозу. Жир практично не впливає на кислотність закваски і незначно поліпшує підйомну силу. Сумісне використання цукру $\mathrm{i}$ жиру незначно впливає на кислотність заквасок, але більшою мірою поліпшує їх підйомну силу. 
Таблиця 7. Вплив рецептурних компонентів на якість закваски та готових виробів

\begin{tabular}{|c|c|c|c|c|c|c|c|c|}
\hline \multirow{3}{*}{$\begin{array}{c}\text { Показник } \\
0\end{array}$} & \multicolumn{8}{|c|}{ Приготування закваски з використанням } \\
\hline & \multicolumn{2}{|c|}{$\begin{array}{c}\text { тільки стартової } \\
\text { культури }\end{array}$} & \multicolumn{2}{|c|}{$\begin{array}{c}\text { стартової } \\
\text { культури і цукру }\end{array}$} & \multicolumn{2}{|c|}{$\begin{array}{c}\text { стартової } \\
\text { культури і жиру }\end{array}$} & \multicolumn{2}{|c|}{$\begin{array}{c}\text { стартової } \\
\text { культури, цукру і } \\
\text { жиру }\end{array}$} \\
\hline & 0,6 & 43 & 0,6 & 40 & 0,6 & 42 & 0,6 & 40 \\
\hline 4 & 1,6 & 49 & 1,8 & 24 & 1,6 & 46 & 1,8 & 17 \\
\hline 8 & 2,2 & 52 & 2,4 & 23 & 2,0 & 50 & 2,6 & 14 \\
\hline 12 & 2,9 & 54 & 3,0 & 45 & 2,8 & 53 & 3,0 & 36 \\
\hline 16 & 3,1 & 301 & 3,3 & 103 & 3,2 & 336 & 3,5 & 109 \\
\hline \multicolumn{9}{|c|}{ Готові вироби } \\
\hline $\begin{array}{c}\text { Питомий об’єм, } \\
\text { cм }^{3} / 100 г\end{array}$ & \multicolumn{2}{|c|}{330} & \multicolumn{2}{|c|}{385} & \multicolumn{2}{|c|}{352} & \multicolumn{2}{|c|}{373} \\
\hline
\end{tabular}

Отже, встановлені залежності впливу технологічних факторів на показники якості заквасок і готових виробів дають змогу регулювати параметри технологічних процесів для забезпечення найкращої якості виробів, обирати правильні управлінські рішення та створюють підгрунтя для подальшого вдосконалення технології виробництва хліба на пшеничних заквасках.

\section{Висновки}

1. Встановлено закономірності впливу вологості й температури на кінетику кислотонакопичення та зміну підйомної сили закваски на стартових культурах LV1. Показано, що кислотність і підйомна сила густих заквасок є вищими порівняно з рідкими заквасками, впродовж перших 6-9 годин бродіння практично не змінюється, що пояснюється домінуванням у цей період процесів розмноження мікроорганізмів над процесом бродіння. Дотримання вищої температури заквасок - $28^{\circ} \mathrm{C}$ сприяє швидшому досягненню необхідної кислотності заквасок і дає змогу скоротити процес їх бродіння з 24 год до 20 год.

2. Доведено, що у разі використання рідкої пшеничної закваски на стартовій культурі LV1 як підкислювача раціонально вносити закваску при приготуванні тіста в кількості 50\% до маси борошна в тісті, що відповідає 20\% борошна, яке вноситься із закваскою.

При використанні закваски на стартовій культурі LV1 як розпушувача для приготування хліба доцільно використовувати густу закваску в кількості, що містить 20\% борошна (в перерахунку на закваску — 31,5\%), та вносити в тісто $0,2 \%$ до маси борошна пресованих дріжджів.

3. Встановлена можливість використання густої закваски на стартовій культурі LV1 як розпушувача для виготовлення здобних виробів без використання пресованих дріжджів. При цьому кількість борошна, що вноситься із закваскою, становить 50\% до маси борошна в тісті; також у закваску вноситься частина цукру, жиру та солі. Якість здобних виробів, виготовлених за цих умов, не поступається якості виробів, виготовлених опарним способом, $\mathrm{i}$ перевершує ії за показниками, що зумовлюють смак та аромат виробів.

4. Експериментально обгрунтована доцільність внесення у закваску цукру та жиру (кожного у кількості 2,5\% до маси борошна) для поліпшення ії підйомної сили та незначного підвищення кислотності. 


\section{Лiтература}

1. Афанасьева О.В. Микробиология хлебопекарного производства. С.-Петерб. фил. гос. НИИ хлебопекар. пром-ти. Санкт-Петербург: Береста, 2003. 220 с.

2. Дробот В.І. Технологія хлібопекарського виробництва. Київ: Логос, 2002. 363 с.

3. Матвеева И.В., Белявская И.Г. Биотехнологические основы приготовления хлеба. Москва: ДеЛи принт, 2001. 150 с.

4. Грегірчак Н.М. Мікробіологія харчових виробництв: [лабор. практикум]. Київ: HУХТ, 2009. $302 \mathrm{c}$.

5. Lesaffre T. The science of sourdough starters: modern science meets ancient chemistry. European baker \& biscuit. 2018. Issues 3. P. 36-39.

6. Besbes E., Le Bail A., Seetharaman K.,. Corsetti A Technology of Sourdough Fermentation and Sourdough Applications. Handbook on Sourdough Biotechnology. Springer, 2013. P. $85-103$.

7. De Vuyst L., Neysens P. The sourdough microflora: biodiversity and metabolic interactions. Trends in Food Science \& Technology. 2005.Volume 16, Issues 1-3. P. 43-56.

8. Galle S. Sourdough: A tool to improve bread structure. Handbook on Sourdough Biotechnology. Springer, 2013. P. 217-228.

9. Gobbetti M. The sourdough microflora: Interactions of lactic acid bacteria and yeasts. Trends in Food Science \& Technology. 1998. Volume 9, Issue 7. P. 267-274.

10. Huys G., Daniel H.-M., De Vuyst L. Taxonomy and biodiversity of sourdough yeasts and lactic acid bacteria. Handbook on Sourdough Biotechnology. Springer, 2013. P. 105-154. 